\title{
Are North Slope Surface Alluvial Fans Pre-Holocene Relicts?
}

\author{
By Erk Reimnitz and Stephen C. Wolf
}

\begin{abstract}
The surface morphology of the northern slope of the Brooks Range (North Slope) from the Canning River, Alaska, eastward is dominated by a series of large alluvial fans and braided streams floored by coarse alluvium. On the basis of the absence of sediment on the seasonal sea ice after spring flooding, the measured stability of fan fronts during a 30year period, and the sparsity or absence of Holocene marine sedimentary deposits seaward of the fans, we conclude that the fans are not prograding now nor have they been prograding at any time during the Holocene. In numerous areas, surficial fan alluvium terminates on land at or below 2-m-thick glaciomarine deposits. These deposits, the Flaxman Member of the Gubik Formation, formed during the latest major interglacial transgression (oxygen-isotope stage 5a), about 85-80 ka. We therefore believe that the fans are still older. Our observations suggest that during the latest transgression and the following sea-level highstand, the North Slope depositional environment and climate differed greatly from the present ones.
\end{abstract}

\section{INTRODUCTION}

The surface morphology of the northern slope of Alaska's Brooks Range, called the North Slope, is dominated by a series of large alluvial fans and braided streams containing coarse alluvium east of the Canning River (fig. 1). We present evidence that these fans are not prograding today, probably were not fully active during Holocene time, and may have acquired their regional, overall characteristics before $80 \mathrm{ka}$, during the latest interglacial transgression. They record the latest major sediment influx from the Brooks Range northward to the Beaufort Sea and Amerasian Basin. Knowing the timing of and conditions for fan construction would be valuable for understanding both the major sedimentation pulses recorded in cores of the Canada Basin, and the climatic conditions that triggered these pulses, as well as possibly for predicting future changes in the sedimentary regime. Understanding the modern hydrologic and depositional conditions of the fans would also be beneficial for any future petroleum development and gravel mining in the Arctic National Wildlife Refuge.

Acknowledgments.-We thank Gita Dunhill and Susan Vath for drafting the illustrations, and Ken Bird, Dave Hopkins, John Andrews, and Kelin Whipple for reviewing the manuscript.

\section{BACKGROUND INFORMATION}

The North Slope has a desert climate, with low precipitation (avg $16 \mathrm{~cm} / \mathrm{yr}$ at Barter Island), which falls mainly in the form of snow (Brewer, 1987). The snow melts during a 10- to 14-day period from late May to early June (Brewer, 1987), thus releasing most of the annual precipitation in a short burst. Much of the meltwater is retained temporarily on land until river breakup around June 1, after which peak discharge lasts only 2 weeks. The largest North Slope river, the Colville River, supplies more than 60 percent of its annual suspended sediment load to the sea during this 2-week period, beginning with river breakup (Arnborg and others, 1967), when rivers flood the fast ice, which is relatively smooth seasonal sea ice, as far as $10 \mathrm{~km}$ or more from their mouths (Reimnitz and Bruder, 1972). Surface sediment on the North Slope, which at that time is still frozen, begins to thaw but again refreezes in late September. In 15 years of records at Barter Island (fig. 2), daily precipitation exceeded $1.3 \mathrm{~cm}$ only three times, commonly as a gentle drizzle during the summer (Brewer, 1987). Thus, floods at breakup are the major yearly sedimentation events. North Slope denudation rates are about $10 \mathrm{t} / \mathrm{km}^{2}$ per year west of the study area (Reimnitz and others, 1988), increasing eastward to $42 \mathrm{t} /$ $\mathrm{km}^{2}$ per year in the Babbage River just east of Herschel Island (fig. 2; Forbes, 1981). Such denudation rates are among the lowest on the globe (Milliman and Meade, 1983).

Along the wide west half of the North Slope coastal plain, average coastal retreat of $2.5 \mathrm{~m} / \mathrm{yr}$ is contributing at least 7 times more sediment to the sea than rivers supply from upland sources (Reimnitz and others, 1988). In the study area, characterized by bluff-retreat rates of $\sim 0.6 \mathrm{~m} / \mathrm{yr}$ (Barnes and others, 1992) and probably higher denudation rates, the ratio might be somewhat lower. Today's general coastal re- 
cession is accompanied by shoreface and shelf erosion seaward to at least 30-m water depth, as shown by data from numerous boreholes correlated with shallow seismic stratigraphy (Wolf and others, 1985, 1987), as well as other observations.
Drainage patterns and topographic contours on maps, as well as Landsat images, reveal a series of large, fanlike features extending from the Brooks Range northward toward the Beaufort Sea coast. A summer Landsat image of two of these fans just west of the United States-Canadian border is

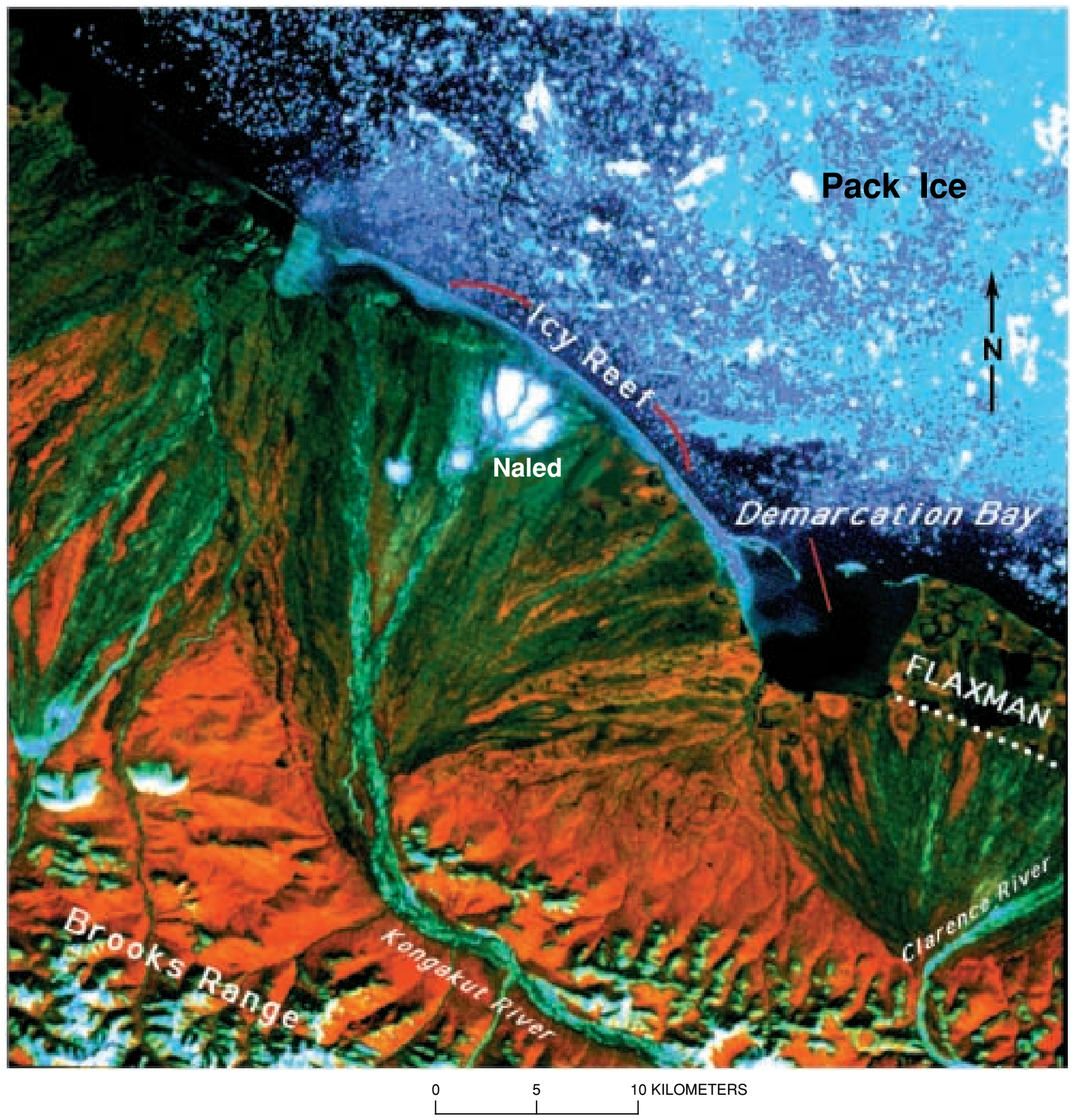

Figure 1. Landsat image of two North Slope fans and braided streams near the United States-Canadian border. The Kongakut Fan is characterized by a perennial naled (river icing) and is protected from pack-ice erosion by Icy Reef, a 26-km-long barrier island.
Configuration of $<1$-m-deep, mud-floored lagoon and reef is remarkably stable over a 30-year period. Dotted line shows landward limit of overlying deposits of the Flaxman Member of the Gubik Formation. 


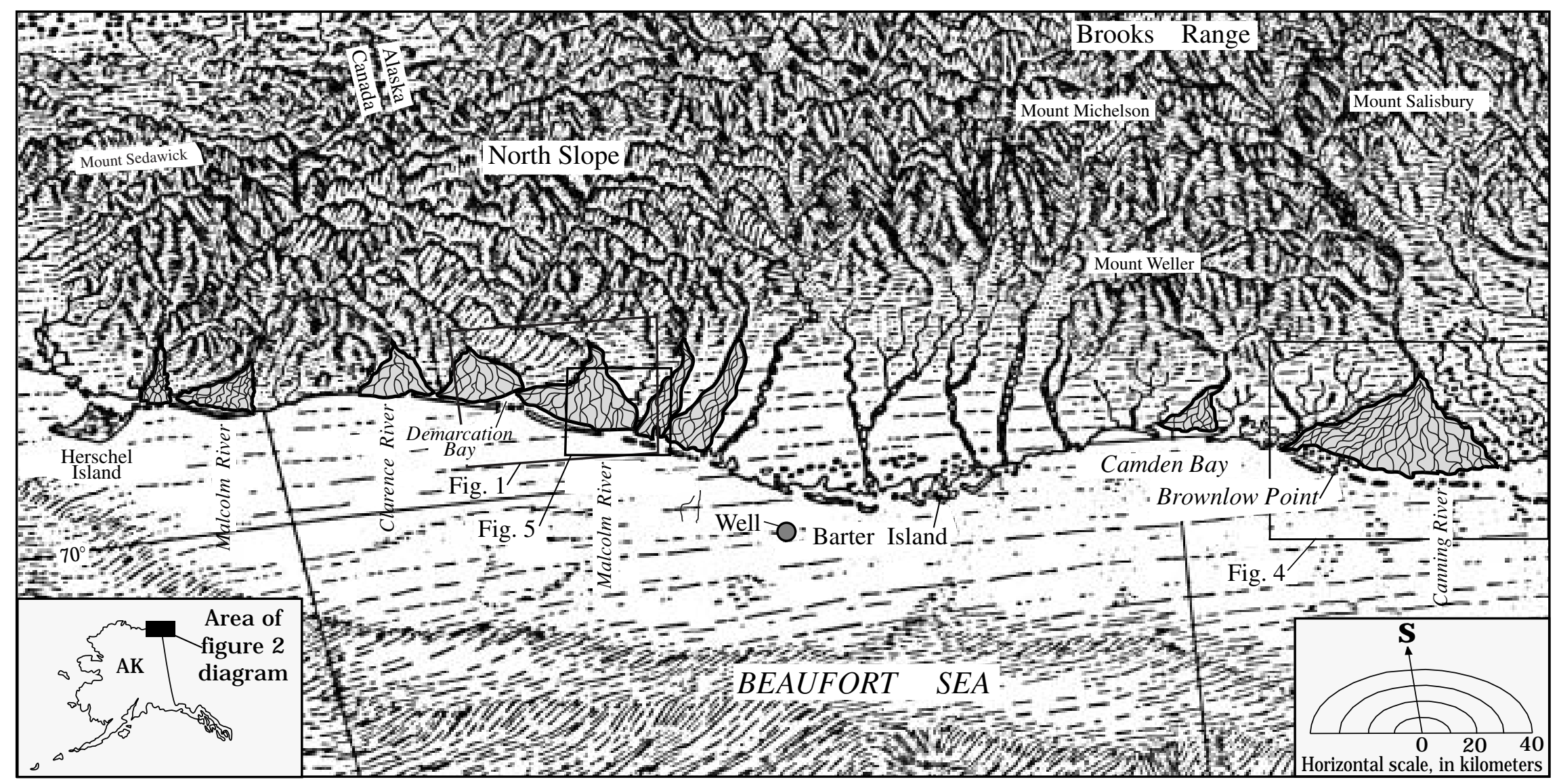

Figure 2. Orthographic map of study area in northern Alaska, showing fans schematically, locations of geographic features referred to in text, and areas of figures 1,3, and 4 (after Alpha and Gerin, 1980). 
shown in figure 1, and the major fans on the North Slope are shown schematically in figure 2. Gradients of fan surfaces increase from about $3 \mathrm{~m} / \mathrm{km}$ on the Canning Fan in the west to about $40 \mathrm{~m} / \mathrm{km}$ on the two eastern fans, where the foothills of the Brooks Range converge with the coast. These fans consist largely of fluvial gravel to sandy gravel, decreasing in clast size toward the coast, and are locally overlain by 1 to $2 \mathrm{~m}$ of eolian silt to fine sand and peat (Carter and others, 1986). Other drainage systems between the Canning and Kongakut Rivers are braided (fig. 2) and are also marked by coarse clast sizes (Carter and others, 1986).

Where the fans meet the Beaufort Sea, the terminus generally is a low, crenulated scarp, suggesting modern erosion (fig. 3). This scarp is most striking along the Canning Fan (fig. 4), which in the subsurface extends offshore as a mainly gravelly unit, approximately $100 \mathrm{~m}$ thick (Lindsay, 1992). A several-meter-thick surficial unit of glaciomarine deposits of oxygen-isotope stage 5a (Carter and Whelan, 1991) constrains the age of the alluvial fans, as shown below. This surficial unit is exposed near sea level in numerous places along the coast (figs. 1, 4; Carter and others, 1988). The unit contains pebbles, cobbles, and boulders of rock types foreign to the Brooks Range that were ice rafted to the area from the Amundsen Gulf region, Canada. The Canning River today is deflected eastward into Camden Bay by relatively high standing ( $>4 \mathrm{~m}$ high) exposures of the Flaxman Member of the Gubik Formation (fig. 4), where it is constructing a small delta into the open sea (Wolf and others, 1987). In contrast, the crenulated shoreline of the Kongakut Fan (fig. 5 ) is bordered by a 500-m-wide, less than 1-m-deep muddy lagoon and an unbroken, 26-km-long, arcuate, 4-m-high gravel barrier (Barnes and Reimnitz, 1988). The Clarence Fan (fig. 1) largely terminates on the coastal plain even before reaching the sea.

\section{EVIDENCE FOR MODERN INACTIVITY RELATIVE TO THE PERIOD OF FAN CONSTRUCTION}

Evidence that the alluvial fans may be relict features is based mainly on four factors: (1) the absence of sediment on fast ice fringing the fans shortly after spring river breakup, (2) the stability or retreat of fan shores during the past 30

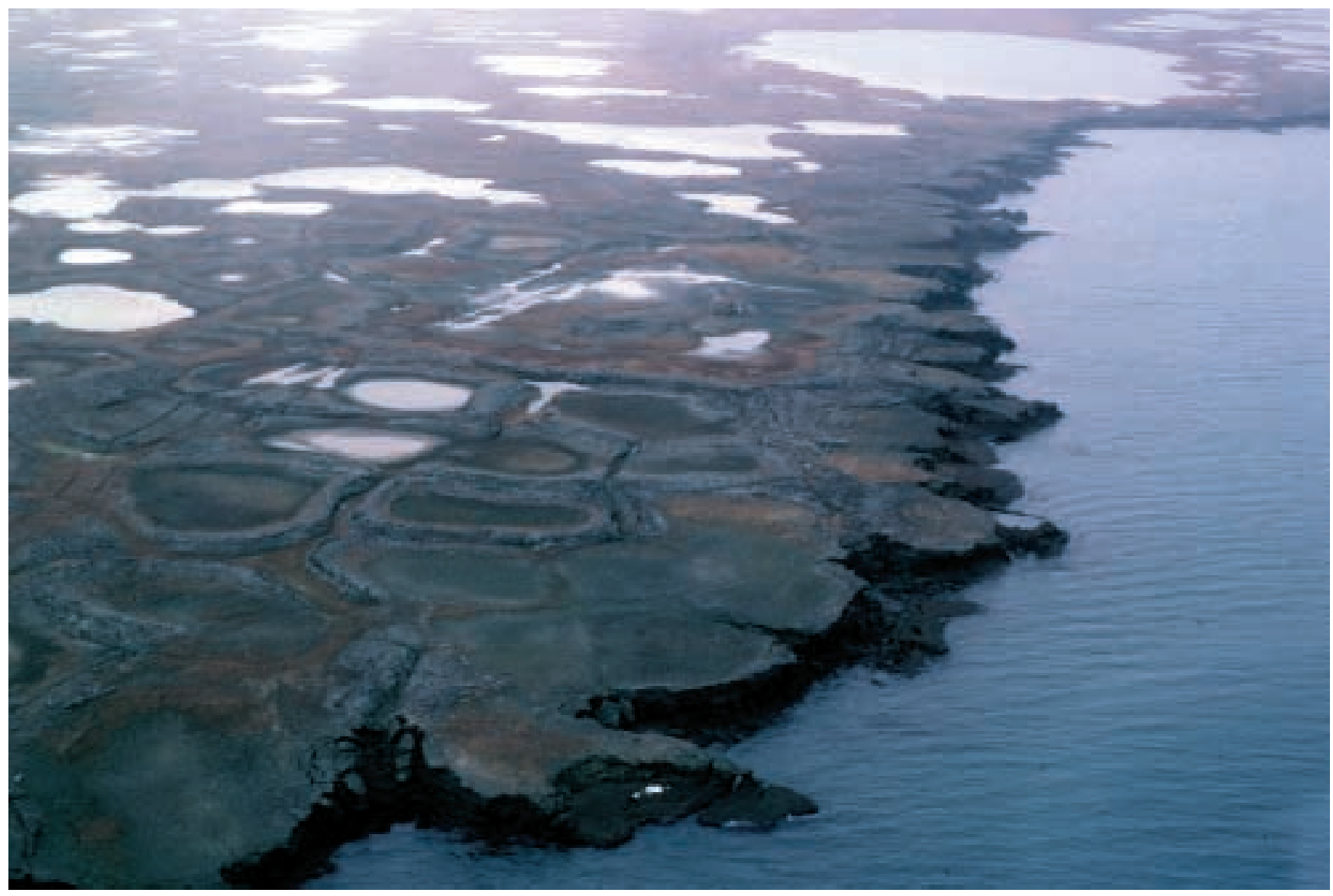

Figure 3. Oblique aerial photograph of evidently eroding coast of the Canning Fan directly south of Flaxman Island (see fig. 4). 
years, (3) the absence of significant Holocene marine deposits in the shallow coastal zone bordering the fans, and (4) the stratigraphic relation of fans and subsurface fan deposits to dated deposits of the Flaxman Member. These four factors show that our view of the modern fan setting is based mainly on knowledge gained in marine geologic studies, and on satellite images: we made no direct studies of fan-surface morphology, stream terraces, and alluvial deposits.

\section{AERIAL OBSERVATIONS OF SEASONAL FAST ICE AFTER SPRING FLOODING}

During an investigation of fast-ice flooding by North Slope rivers, a coastal reconnaissance and photographic mis- sion was made, covering most of the North Slope coast, notably where the large fans terminate (Reimnitz and Bruder, 1972). Several-kilometer-diameter patches of open water already had formed off the major river mouths by June 21 , 1970 , similar to, but smaller than, the areas of open water shown in figure 5. Regionally, however, the smooth and clean fast-ice cover remained intact against the coast, revealing in some places areas that previously had been flooded and then drained.

The absence of sediment on the fast ice bordering the fans at a time when the bulk of the annual river supply had just been flushed to sea indicates that the fans were not prograding that year. Satellite images and aerial photographs available for subsequent years (fig. 5) show that the 1970 breakup was normal.

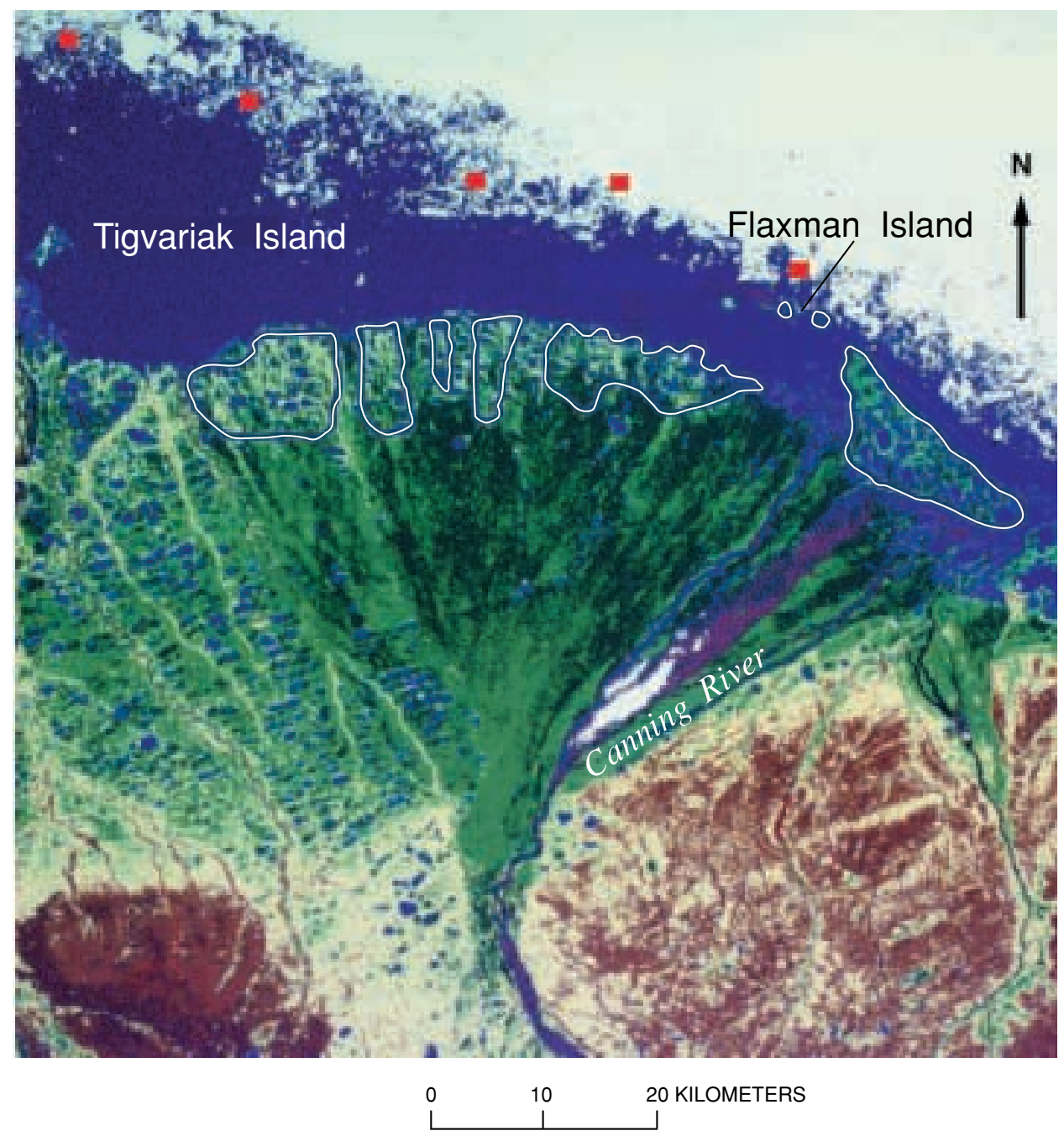

Figure 4. Landsat image of the Canning Fan, showing crenulated, bluffed, eroding shoreline. Extensive outcrops of 85-80-ka glaciomarine sedimentary deposits (Flaxman Member of the Gubik Formation) are delineated. Main river distributary presently is deflected at nearly right angle eastward by the Flaxman Member. Squares, boreholes. 


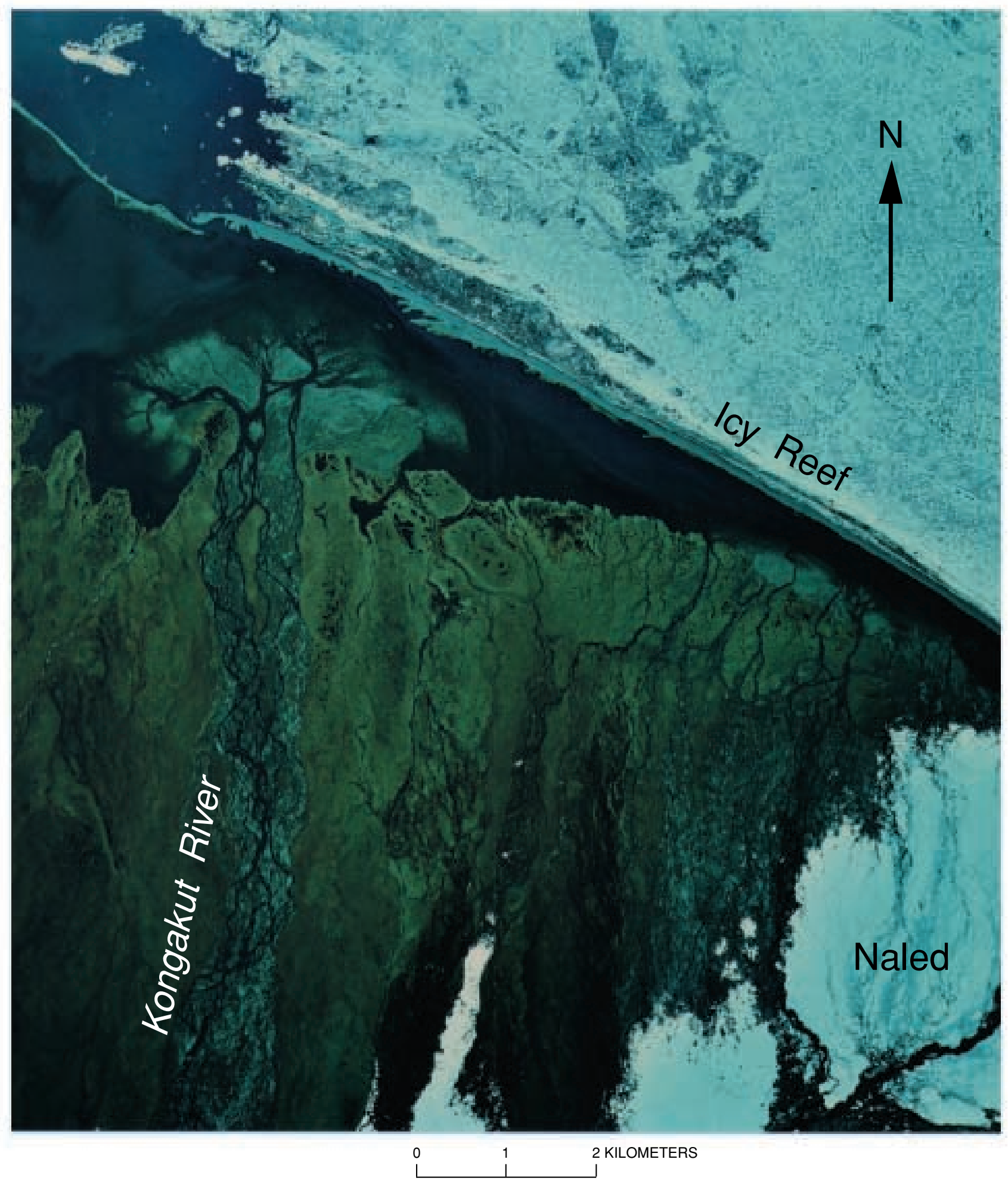

Figure 5. Presently active mouth of the Kongakut River, which has built a large fan, partly visible on right. During spring flood 4 weeks earlier, the river probably discharged onto ice through tidal inlets, but no surface sediment is visible on its remnants or on drifting floes. From 1951 to 1981, fan and delta on left locally showed minor deposition and elsewhere erosion (Barnes and others, 1992), whereas barrier islands had minor net land loss. Aerial photograph by U.S. National Aeronautic and Space Administration, Johnson Space Center, taken July 8, 1978. 


\section{STABILITY OR RETREAT OF THE COASTLINE}

From the United States-Canadian border westward, the bluffed fan shores shown in figure 3 have been either stable or retreating during a 30-year period (Barnes and others, 1992). Although small deltas have accreted off river mouths during that period, these fine-grained deposits, reaching to less than $25 \mathrm{~cm}$ above sea level, can be ignored when considering modern fan accretion. On the Canadian side of the border, fan shores also are stable (Harper, 1990). Along the entire coast from the Kongakut River eastward (fig. 2), fans typically are separated from the ocean by rather stable gravelly beaches or barrier islands backed by narrow, shallow lagoons (Barnes and Reimnitz, 1988; Reimnitz and Barnes, 1988; Harper, 1990; Barnes and others, 1992). These stable landforms are not nourished by sediment from rivers (Harper, 1990; Barnes and others, 1992) but from offshore by ice push (Reimnitz and others, 1990). Where the crenulated outline of the Canning Fan meets the lagoon (figs. 3, 4), it is erosional, with 1- to 2-m-high bluffs. The setting depicted in figure 3, a low-level aerial photograph, is typical for the outline of the fan-its sloping surface nowhere grades into the sea. An analysis of coastal landforms and deposits off the fans therefore clearly indicates that they are not accreting today.

\section{SPARSITY OF HOLOCENE MARINE DEPOSITS}

Interpretation of high-resolution seismic profiles in the study area shows that the shelf at present is largely an erosional surface (Wolf and others, 1985, 1987; Reimnitz and Barnes, 1987). The shelf truncates two units correlated with the latest two interglacial intervals (Wolf and others, 1987). Lithologic studies of pebbles on the island chain extending westward from the Canning River and fan show only a weak influence of Brooks Range sources (Reimnitz and others, 1990). Wolf and others (1987) constructed an isopach map of a small Holocene delta off the mouth of the Canning River in Camden Bay (fig. 2), and of shallow pockets of Holocene sedimentary deposits in lagoons and bays. The sheltered confines of Demarcation Bay (fig. 1) between two conspicuous alluvial fans hold only a small pocket containing no more than $4 \mathrm{~m}$ of fine-grained Holocene sediment (fig. 6) lacking evidence for internal deltaic structures. The fine-grained Holocene deposits observed in small pockets seaward of the fans, and the absence of modern gravel supply, also indicate that the fans are not prograding today.

\section{RELATION OF THE FANS TO GLACIOMARINE DEPOSITS}

Numerous exposures of glaciomarine deposits of the Flaxman Member of the Gubik Formation, commonly blan- keted by a several-meter-thick veneer of eolian sand and silt, were mapped by Carter and others $(1986,1988)$, particularly along the fringes of the Canning Fan (fig. 4), as well as on other fans reaching eastward as far as the United StatesCanadian border (fig. 2). The exact relation of the fans to deposits of the Flaxman Member and the nature of their contact is unknown because of a thin surface blanket of loess (L.D. Carter and J.P. Galloway, oral communs., 1995); however, analysis of figure 1 suggests that major surface-modifying processes on the Clarence Fan ended before deposition of the Flaxman Member. Furthermore, computer modeling by Lindsay (1992) of Canning Fan sediment penetrated in 1,224 boreholes, reaching as deep as $104 \mathrm{~m}$, indicate that the Flaxman Member, as described earlier (fig. 4), overlies a series of offshore-dipping gravelly strata extending seaward as far as the island chain (fig. 2). Sediment of the Flaxman Member was deposited during the latest sea-level highstand (Carter and others, 1988, 1991), about 85-80 ka, suggesting that main fan construction ended before that time.

\section{DISCUSSION AND CONCLUSIONS}

Our hypothesis that since before Flaxman time North Slope drainage systems have provided insufficient sediment for further fan growth is controversial but consistent with the available data. It requires that the next-to-latest

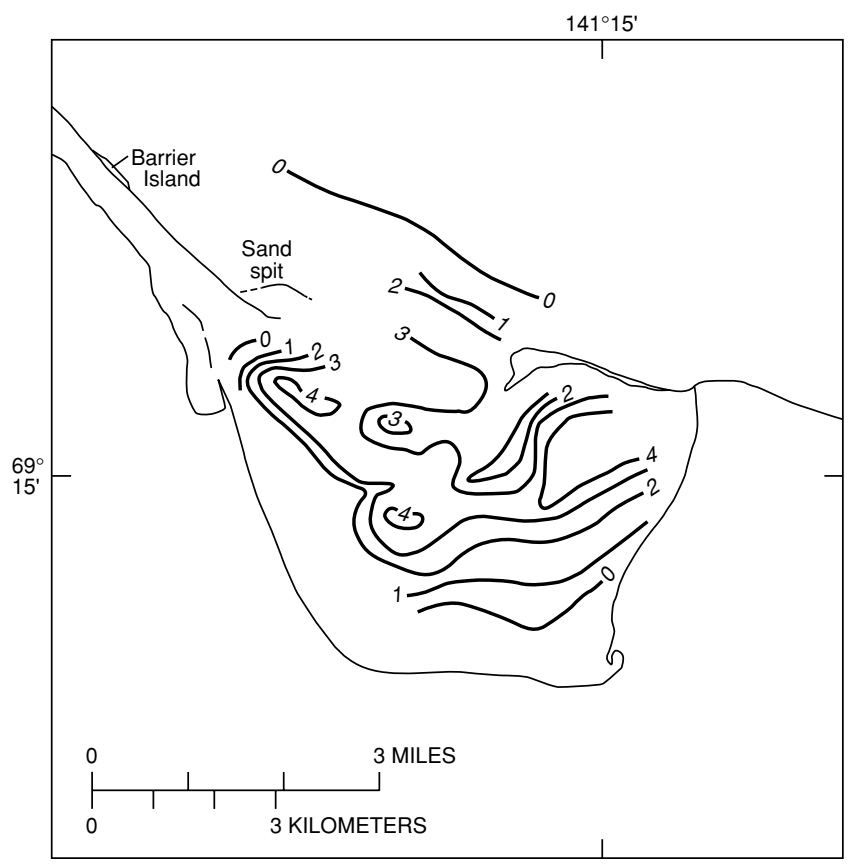

Figure 6. Geophysical tracklines in Demarcation Bay (fig. 1). Contours show thickness of Holocene(?) marine sediment (in meters) (Wolf and others, 1987). Absence of foreset beds in seismic records adjacent to fans shows nonoccurrence of fan progradation during the Holocene in this sheltered embayment. 
deglaciation produced much more coarse alluvium than did the latest one. That previous period differed in other respects as well. Thus, Arctic coastal waters reached a higher level and were warmer and more turbid, and the winter sea-ice limit was $800 \mathrm{~km}$ farther north, than today (Carter and others, 1988; Brigham-Grette and others, 1994; Carter and Whelan, 1991, 1994). The interpretation that muddy deposits of the Flaxman Member accumulated at depths less than $20 \mathrm{~m}$ (Carter and others, 1988), an environment marked by erosion today (Barnes and others, 1987; Reimnitz and Barnes, 1987; Reimnitz and others, 1988), is convincing evidence that conditions indeed differed drastically. Further evidence for a drastically different depositional environment during that period and even the previous interglacial stage is visible in two inner-shelf marine units identified in numerous boreholes and traced by seismic-reflection profiles over wide areas (Wolf and others, 1985, 1987). Here, as well, the region marked by deposition during the latest two interglacial stages is presently eroding.

We speculate that the coarse glacial-outwash fans were most active during rapid glacial retreat coupled with high meltwater discharge. For understanding land-sea interaction during the latest glacial-interglacial cycles, knowledge that fan deposition extended several times well beyond the present shoreline is important. A pre-Flaxman fan surface had been traced by way of seismic reflectors offshore to a 125,000 -yr-old erosional unconformity penetrated by five boreholes shown in figure 4 (Smith, 1985; Wolf and others, 1987, fig. 6.19). This position suggests that the fan formed before $125 \mathrm{ka}$, and the absence of coarse alluvium above the unconformity (Smith, 1985) indicates that fan deposition had ended in this region. A drill hole near the 20-m isobath east of Barter Island (fig. 2) penetrated $30 \mathrm{~m}$ of gravel, indicating that in this area coarse alluvium spilled seaward as far as the midshelf.

During peak times for fan construction, streams of turbid meltwater flowing across the partly exposed shelf should have caused increased sedimentation rates and, probably, a coarsening of the sedimentary record in the Canada Basin to the north. Such coarsening is evident during the early part of the latest interglacial stage in cores from Northwind Ridge (R.L. Phillips, oral commun., 1995).

In summary, the presence of large alluvial fans of northern Alaska, never acknowledged in the literature as not prograding today, raises significant unanswered questions about the North Slope environment. Learning about the period of fan construction and environmental conditions during that time would be valuable for understanding late Pleistocene global change and, particularly, for understanding differences between the latest several glacial/interglacial transitions.

\section{REFERENCES CITED}

Alpha, T.R., and Gerin, Marybeth, 1980, Oblique map of the Beau- fort Sea and the Brooks Range of Alaska: U.S. Geological Survey Open-File Report 80-455, scale 1:1,000.000.

Arnborg, Lennart, Walker, H.J., and Peippo, Johan, 1967, Suspended load in the Colville River, Alaska, 1962: Geografiska Annaler, v. 48 , ser. A, no. $2-4$, p. 131-144.

Barnes, P.W., Ashbury, J.L., Rearic, D.M., and Ross, C.R., 1987, Ice erosion of a sea-floor knickpoint at the inner edge of the stamukhi zone, Beaufort Sea, Alaska: Marine Geology, v. 76, no. 3-4, p. 207-222.

Barnes, P.W., and Reimnitz, Erk, 1988, Construction of an arctic barrier island by alternating sea ice pile-up and overwash, in Galloway, J.P., and Hamilton, T.D., eds., U.S. Geological Survey studies during 1987: U.S. Geological Survey Circular 1016, p. 180-182.

Barnes, P.W., Reimnitz, Erk, and Rollyson, B.P., 1992, Map showing Beaufort Sea coastal erosion and accretion between Flaxman Island and the Canadian border, northeastern Alaska: U.S. Geological Survey Miscellaneous Investigations Series Map I-1182-H, scale 1:82,000.

Brewer, M.C., 1987, Surficial geology, permafrost, and physical processes, in Bird, K.J., and Magoon, L.B., eds., Petroleum geology of the northern part of the Arctic National Wildlife Refuge, northern Alaska: U.S. Geological Survey Bulletin 1778 , p. 27-36.

Brigham-Grette, Julie, Hopkins, D.M., Carter, L.D., Kaufman, D.S., and Marincovich, L.N., 1994, Character and climate of the last interglacial (Oxygen isotope stage 5e) in the Bering Strait and Arctic Alaska as determined from nearshore marine deposits [abs.]: Geological Society of America, Annual Meeting, Seattle,1994, Abstracts with Programs, p. A-514.

Carter, L.D., Brouwers, E.M., and Marincovich, Louie, Jr., 1988, Nearshore marine environments of the Alaskan Beaufort Sea during deposition of the Flaxman Member of the Gubik Formation, in Galloway, J.P., and Hamilton, T.D., eds., Geologic Studies in Alaska by the U.S. Geological Survey during 1987: U.S. Geological Survey Circular 1016, p. 27-30.

Carter, L.D., Ferrians, O.J., Jr., and Galloway, J.P., 1986, Engineering-geologic maps of northern Alaska coastal plain and foothills of the Arctic National Wildlife Refuge: U.S. Geological Survey Open-File Report 86-334, scale 1:250,000, 2 sheets.

Carter, L.D., and Whelan, J.F., 1991, Isotopic evidence for restricted Arctic sea ice during a Late Pleistocene warm period; implications for sea ice during future climatic warming at high latitudes [abs.]: Geological Society of America Annual Meeting, San Diego, Calif., 1991, Abstracts with Programs, p. A-237.

1994, The last interglacial along the Arctic coast of Alaska [abs.]: Geological Society of America Annual Meeting, Seattle, 1994, Abstracts with Programs, p. A-236.

Forbes, D.L., 1981, Babbage River delta and lagoon; hydrology and sedimentology of an arctic estuarine system: Vancouver, British Columbia, Canada, University of British Columbia, Ph.D. thesis, $554 \mathrm{p}$.

Harper, J.R., 1990, Morphology of the Canadian Beaufort Sea coast: Marine Geology, v. 91, no. 1-2, p. 75-91.

Lindsay, J.F., 1992, Three-dimensional geologic block model of a polar fan-delta complex, Canning River, North Slope, Alaska, in Hamilton, D.E., and Jones, T.A., Computer modeling of geologic surfaces and volumes (AAPG Computer Applications in Geology 1): Tulsa, Okla., American Association of Petroleum Geologists, p. 183-200. 
Milliman, J.D., and Meade, R.H., 1983, World-wide delivery of river sediment to the oceans: Journal of Geology, v. 91, no. 1, p. 1-21.

Reimnitz, Erk, and Barnes, P.W., 1987, Sea-ice influence on Arctic coastal retreat, in Kraus, N.E., ed., Coastal sediments 1987: New Orleans, American Society of Civil Engineers, v. 2, p. 1578-1591.

1988, Evidence for sea-ice impact on Icy Reef, Beaufort Sea coast, in Galloway, J.P., and Hamilton, T.D., eds., Geologic studies in Alaska by the U.S. Geological Survey during 1987: U.S. Geological Survey Circular 1016, p. 190-192.

Reimnitz, Erk, Barnes, P.W., and Harper, J.R., 1990, A review of beach nourishment from ice transport of shoreface materials, Beaufort Sea, Alaska: Journal of Coastal Research, v. 6, no. 2, p. 439-470.

Reimnitz, Erk, and Bruder, K.F., 1972, River discharge into an icecovered ocean and related sediment dispersal, Beaufort Sea, coast of Alaska: Geological Society of America Bulletin, v. 83 , no. 3, p. 861-866.
Reimnitz, Erk, Graves, S.M., and Barnes, P.W., 1988, Beaufort Sea coastal erosion, sediment flux, shoreline evolution, and the erosional shelf profile: U.S. Geological Survey Miscellaneous Investigations Series Map I-1182-G, 22 p., scale 1:82,000.

Smith, P.A., 1985, Late Quaternary geology of the Beaufort Sea inner shelf near Prudhoe Bay, in Bartsch-Winkler, Susan, and Reed, K.M., eds., The United States Geological Survey in Alaska; accomplishments during 1983: U.S. Geological Survey Circular 945, p. 100-103.

Wolf, S.C., Barnes, P.W., Rearic, D.M., and Reimnitz, Erk, 1987, Quaternary seismic stratigraphy of the inner continental shelf north of the Arctic National Wildlife Refuge, in Bird, K.J., and Magoon, L.B., eds., Petroleum geology of the northern part of the Arctic National Wildlife Refuge, northern Alaska: U.S. Geological Survey Bulletin 1778, p. 61-78.

Wolf, S.C., Reimnitz, Erk, and Barnes, P.W., 1985, Pleistocene and Holocene seismic stratigraphy between the Canning River and Prudhoe Bay, Beaufort Sea, Alaska: U.S. Geological Survey Open File Report 85-549, 50 p. 